\title{
Indonesian students' perceived benefits of the micro- teaching course to their teaching internship
}

\author{
Teuku Zulfikar*, Nidawati, Siti Khasinah, and Indah Mayangsari \\ Department of English Language Education, Faculty of Education and Teacher Training, \\ Universitas Islam Negeri Ar-Raniry Banda Aceh, Indonesia
}

\begin{tabular}{|c|c|}
\hline \multirow{2}{*}{\multicolumn{2}{|c|}{$\begin{array}{l}\text { ABSTRACT } \\
\text { This study aims to explore student-teachers' perceptions of the benefits of micro-teaching class } \\
\text { they have attended to their teaching internship. It also seeks to identify the most and the least } \\
\text { likely aspects of teaching which have been sufficiently covered in the micro-teaching course. The } \\
\text { participants of this study were ten senior EFL students at a State Islamic University in Indonesia } \\
\text { who have taken a micro-teaching class and teaching internship program. The data from interviews } \\
\text { and students' written narratives reveal that these students perceive the micro-teaching class to be } \\
\text { sufficiently helpful in their teaching internship phase. These students developed their basic } \\
\text { pedagogical skills. They become more confident; develop communication skills, and most } \\
\text { importantly, the micro-teaching class has helped them develop questioning skills. However, } \\
\text { students' interviews and written narratives also indicate that management skills, such as } \\
\text { classroom and time management, and skills to write lesson plan are the least likely aspect of } \\
\text { teaching covered during the micro-teaching class, which then become obstacles for them during } \\
\text { their teaching internship. } \\
\text { Keywords: Classroom management; management skills; micro-teaching; teaching internship }\end{array}$}} \\
\hline & \\
\hline $\begin{array}{l}\text { First Received: } \\
\text { 14 February } 2020 \\
\text { Final Proof Received: } \\
20 \text { May } 2020\end{array}$ & Acc \\
\hline How to cite (in APA style): & \\
\hline
\end{tabular}

\section{INTRODUCTION}

The College of Education and Teacher Training is aimed at producing qualified teachers. To prepare qualified teacher-candidates, the college offers two important programs: the micro-teaching and the teaching internship courses. Prior to actually engage in teaching internship, students should first enroll in the micro-teaching class to prepare themselves in their internship program. The micro-teaching aims at developing student-teachers' basic skills in teaching such as the way they start teaching, steps in teachinglearning activities and also classroom management (Kılıç, 2010; Şen, 2009, 2010). To achieve these aims, student-teachers should be given the opportunity to practice their teaching skills during the micro-teaching class under the proper guidance of their lecturers, which is expected to contribute to their professional development (Alibakhshi \& Dehvari, 2015; Hastings \& Squires, 2002; Özbal, 2019). In micro-teaching class, students teach in a micro-classthe small class, in which their classmates as audiences. As it is micro, student-teachers teach in a small group of students consisting of their classmates of ten students. During the program, the studentteachers receive feedbacks from their peers and also their lecturers (Saban \& Çoklar, 2013). This suggests that micro-teaching is a crucial part of the program to train and prepare student-teachers prior to teaching internship.

In addition, the student-teachers develop their teaching strategies; learn how to understand learning interests of prospective students, and more interestingly, they gain knowledge on how to deliver teaching materials and how to development materials

\footnotetext{
* Corresponding Author

Email: teuku.zulfikar@ar-raniry.ac.id
} 
(Alibakhshi \& Dehvari, 2015; Hastings \& Squires, 2002; Özbal, 2019). In addition, Rahayuningsih (2016) believes that micro teaching shapes learning interest of student-teachers participating in the microteaching class, which in turn, enhances their likelihood to succeed in learning.

Having taken the micro-teaching class, studentteachers should enroll in another teaching-related subject, the teaching internship. Unlike the microteaching class, the teaching internship requires student-teachers to engage in more complex and challenging situations, in which these students are transferred to schools to engage in real classroom teaching, in which real students as their audience. The teaching internship is a core-subject, in which all students are obliged to undertake. During the internship, student-teachers learn from real teaching experience. Tuli and File (2009) argued that teacher education program should offer programs allowing student-teachers to shape their professional competence, and the teaching internship is meant to meet that purpose, and this is because qualified teachers guarantee quality education (Zulfikar, 2009). As the teaching internship is a more challenging program, the micro-teaching was designed to help student-teachers prepare for the internship program.

However, it is also important to understand if student-teachers taking the micro-teaching class see the course has been sufficiently helpful in their teaching internship. It is for that reason that this work is aimed at exploring student-teachers' voices on their experience during the micro-teaching class, and if these experiences enhance their readiness for teaching internship. To guide this work, we raised several questions: Do student-teachers taking teaching internship perceive micro-teaching class as an adequate preparation for that task? What aspects of teaching are not sufficiently covered in the microteaching course? These inquiries were addressed using in-depth interviews and students' written journals.

Studies on similar issues have been conducted by Bulut (2016) who investigated the effect of microteaching course of the pre-service teachers in Turkish educational settings. The objective of this research was to find out the pre-service teachers' view in relation to the effect of the micro-teaching course on their verbal communication skills. The result revealed that micro-teaching course made a significant contribution to develop verbal communication skills such as stress, intonation, and diction. The study by Kabilan (2013) also found that teaching practicum participated by pre-service teachers in a Malaysian university has benefitted them in a way that increase their skills, knowledge, and self-confidence. Similar findings were also found in studies by Pence and Macgillivray (2008) and Rodriguez (2011). In addition, research by Barkhuizen and Feryok (2006); Ward and Ward
(2003) and Willard-Holt (2001) found that teaching practicum improves pre-service teachers' professional competence.

Yilmaz (2018) also conducted research in the Turkish context in regard with the benefit of teaching practicum. The finding of the study suggests that preservice teachers develop their self-concept as the result of their participation in the practicum program. In the same context, Saban and Çoklar (2013) found that micro teaching class allows pre-service teachers to reflect on their strengths and weaknesses in teaching. The class also helps these pre-service teachers to develop their questioning skills, time management, and effective uses of teaching materials.

As previous studies yielded diverse results, it is timely to conduct research on student-teachers' perceived benefits of the micro-teaching class on their teaching internship. This current research, thus, seeks to fill in the gaps of those previous works, since it has different research sites and focus.

\section{The micro-teaching}

The micro-teaching is defined as a method basically used in a teacher education program to train studentteachers regularly by allowing them to practice teaching activities as a real teacher in the classroom (Uzun, 2012). It is a specialized design course to provide student-teachers a chance to develop their skills of teaching by practicing teaching (Chaudary et al., 2015). In addition, micro-teaching can also be defined as a simulation which is designed systematically for the teacher candidates in exploring pedagogical experiences, reducing their mistakes in teaching before they start their teaching practices in real classes, mainly implement the knowledge about teaching that they have learned into action (Bulut, 2016)

In addition, the micro-teaching facilitates student-teachers to practice their teaching skills. Remesh (2013) states that micro-teaching provides an opportunity for students to teach in a micro-class, which resembles real teaching experience. The main objective of the course is to prepare students with sufficient pedagogical skills. The course also aims at shaping student-teachers' attitudes.

\section{Teaching internship}

The teaching internship is a core subject in any teacher education program. The course allows student to practice and develop their skills of teaching in a real school context. Zeichner (2010) suggests that the teaching internship is also an important component in the teacher education program, since it provides opportunities for students to have a real teaching experience at schools. During the course, the student-teachers are sent to schools under the supervision of their mentor teachers and also supervisors. In that particular course, studentteachers play a real teaching role, in which they are 
responsible to do all teaching administrative components, such as preparing syllabus, lesson plans, and teaching experience. Ekşi and Yakışık (2016) explained that in teaching internship, studentteachers prepare school administrations to teach several aspects, topics or skills, and supervisors from the faculty will assist and assess them.

As students teach in real schools, their engagement in the internship is not without challenges. They may encounter socio-cultural issues of the schools. They have to fulfill their mentors' expectation and also adjust to their school environment. Unlike being in the micro-teaching course, the teaching internship is indeed exposed students to the situation, which is not necessarily controllable to them.

\section{METHOD}

This is a qualitative research, which focuses on exploring student-teachers' perception on the significant contribution of micro-teaching class on their teaching internship at schools. As the nature of this inquiry, we believed that qualitative research is appropriate to explore people's perceptions, attitudes, and interpretations of situations they are in (Mohajan, 2018). The data was generated using semi-structured interviews and the analysis of student-teachers' personal written narratives. Prior to interviewing participants, we prepared some interview questions, but these questions were developed along the way following the course of the interview. To guarantee the credibility of the data, we transcribed interviews, interpreted the transcripts, and we shared our interpretations of the participants' voices to clarify if we have interpreted their information correctly (Creswell, 2014; Glesne, 2015). In addition, we collected students' written narratives on how the micro-teaching class has helped them prepare for their teaching internship program. The narratives were written weekly. Reviewing their narratives allowed us to obtain more insights on participants' voices.

The participants of this study were some EFL students taking teaching internship. These ten participants were recruited using purposive sampling technique as it allows us to determine appropriate participants to answer our research inquiries. We did not recruit our students to be participants to avoid research subjectivities. The data was analyzed using coding techniques; open, axial and selective coding techniques, referring to Babbie's (2016), Gibb's (2018), and Silverman's $(2017 ; 2020)$ techniques of qualitative data analysis. This technique allows us to organize findings into coding and themes to allow readable data. Student-teachers' quotations used as the data were written as it was said by the participants without any language revisions. Participants in this study were addressed with pseudonym.

\section{FINDINGS}

The interviews and personal written narratives we analyzed show important findings that answer our research inquiries.

\section{The benefits of micro-teaching for teaching internship}

All participants in this research perceived the significant benefits of micro-teaching course on their teaching internship. They stated six benefits of micro teaching on their teaching internship: boosting their self-confidence, improving teaching strategies, enhancing their communication skill, improving their chalkboard skill, increasing student-teachers' questioning skill, and developing these participants' reinforcement skill.

\section{Boosting student-teachers' self-confidence}

All student-teachers participating in this research agreed that micro-teaching helped them increase their confidence. During micro-teaching course, the participants had prepared to face their own anxiety in their teaching internship. Vetra, one of the participants said:

"I became more confident when I taughtin teaching practicum because I have been prepared and did some practices on how to teach well in front of my friends who acted to be a student in the microteaching class. So it could reduce my nervousness".

In her written narrative, she also noted that:

Micro-teaching helped me in boosting my confidence. I did some practice on
how to teach well in front of my peers during the micro-teaching class. So, it
could reduce my nervous in teaching practicum. Before I did some practice I
was not confident to teach in front of people (Vetra's Reflective joumal).

Similarly, Angeline believed that the micro-teaching course developed her self-confidence, in which she was able to speak up in the classroom. She mentioned:

"We knew that in our micro-teaching class we needed to teach and spoke in front of our friends. So we required to speak, learned the materials and taught how to stand up in front of the class. So it taught us to be more confident. So in teaching practicum, we already knew how to stand up and speak in front of the students. So it really helped me to boost my confidence.

Angelina's written narrative also suggests the same note:

My micro-teaching course lecturer supported me to have more capabilities in teaching by allowing me to teach in his nunning courses at the college. It really influenced my confidence in teaching because I already had some teaching experience in micro-teaching. So, the experiences that I gained to teach in real class could increase my confidence in teaching. (Angeline's Reflective joumal).

These two student-teachers believed that microteaching class gave them opportunities to improve their self-confidence as the result of practicing teaching during the course. Angelina, for example reiterated in her written narrative that her experience 
practicing teaching in the micro-teaching class has helped her boost teaching confidence.

\section{Developing teaching awareness and strategies}

The participants also agreed that micro-teaching was an important course for them to take, since they saw it as a pre-requisite course prior to taking other core subject, the teaching internship. They argued that they were benefited from feedbacks given by their mentors and also from their peers. These feedbacks have enabled them to be aware of the 'so called' effective teaching strategies. Mawar, for example said:

"In micro-teaching class, I got some feedbacks that were really useful when I did teaching internship. Especially for chalkboard skills, it sounded like a really simple thing but it gave a big impact for me since it's a fact that how we managed our way of writing on the whiteboard was a crucial thing for students' understanding".

A similar note was also voiced by Mawar in her written narrative. She noted that the feedbacks she received from peers and mentors were very much useful in her teaching internship.

The feedback that I got in micro-teaching was beneficial toward my teaching practicum. I did practice several times of teaching in micro-teaching class the first one was like pre-practice, the second one was like the mid-practice and the last one was the final. In micro-teaching class I taught my fiends but I could imagine how the real classrooms look like. In addition, I got several feedbacks like when I spoke in front of the class I should volume up my voice. So, in teaching practicum, it was really useful to adjust my voice based on the condition in the classroom. The way how to communicate with my students also the important one I got. (Mawar's Reflective Joumal).

Similarly, Angeline claimed that microteaching assisted her to identify her strengths and weaknesses. She wrote in her written narrative that micro-teaching was useful to detect the mistakes in her teaching. The criticisms given by the lecturers and colleagues were constructive to reflect on her experience in teaching. Those feedbacks enabled her to minimize her mistakes made during teaching practices.

The criticisms gave by the lecturer were valuable for my development and it was important to identify my weaknesses in teaching. I also noted some suggestions that my friends made for me. I should do this and avoid some negatives aspects in the leaming process. For instance, in managed group I always focused on a number of groups but it should not do like that I must care for all of them. (Angeline's Reflective joumal).

Furthermore, Alex believed that micro-teaching benefitted him in his teaching internship as he could observe his peers' classroom practices. He mentioned that observing his peers' classroom performance gave him insights on 'effective' teaching strategies. Alex, for example said:

"Micro-teaching also provided a chance to watch my peers' performance and compare them with mine. So, I learned new teaching styles and got some of their creative activities while observing my friends who did a presentation"
The quote suggested that micro-teaching class gave them spaces to learn from their peers' and mentor's feedback. As he observed his peers' teaching, Alex was able to use 'the so called' good teaching during his teaching internship.

\section{Enhancing student-teachers' communication skill}

The participants also mentioned that the microteaching improved their communication skills, and the skills were very useful during their teaching internship. Iqbal told:

"Micro-teaching was beneficial in preparing me to communicate properly. It made me more aware of the word that we used in the classroom. I did not notice that I used the word "nah" and "eeee" quite a lot during my micro-teaching class. My lecturer said that I should not do it; it would make our students distrust and think we did not understand the materials that we taught for them. It was really useful for me to avoid these words in my teaching practicum"

In addition, student-teachers in this research stated that the experience they got from microteaching helped them in adjusting language or communication based on the level of students. It gave them the knowledge on how they should interact and build a good interaction with the students in different levels of grade. The teacher could build enjoyable communication with students by adding some humors and other fun things. This knowledge was indeed important in their teaching internship. Tansa, for example stated:

"In communication with the students, the teachers should not be awkward. We should add some humor to attract their attention to engage them in my teaching. Also when there were some of my students that did not care from my teaching I could call their name to answer the question related to the materials in order to make them payattention".

In addition, student-teachers stated that it was important to build a good interaction with the students to create a comfortable learning atmosphere which helped them understand in a better way. It was necessary to understand the young soul. Therefore, it was needed to adjust the language based on the student's grade. The ability to communicate well was indeed important in their teaching internship. Nelly, for example said:

"It also provided me the best way how to communicate with different levels of my students. So just like we knew, we have different gap ages between the teacher and also the students. When we taught the students who were still junior high schools, we should make the atmosphere in the classroom more cheerful by making fun things. So the micro-teaching class provided me the way how to communicate effectively with our students".

Nelly argued that being able to communicate effectively was important, and that helped her communicate better during teaching internship. 
Moreover, Soraya noted that she also learned how to use voice appropriately in front of the class. Micro-teaching gave a chance to arrange the voice when she conveyed the materials during the teachinglearning process. So, it made the students hear the voice in explaining the lesson clearly. She stated:

"I should control the volume and intonation of my voice not too loud or small. So that all of the students able to hear and understand my explanation easily. Moreover, I should explain the material to the students clearly and straightforward so the students would not be confused with the explanation".

These quotes suggest that micro-teaching course taught them how to communicate well during instructional process, and thus the skills allowed them to be more skillful during teaching internship. However, Soraya argued that communication skill she has developed during the micro-teaching course did not help her communicate more effectively during teaching internship for some reasons.

The communication skill which I got from micro-teaching seemed useless in my teaching practicum. The real students were noisier than my colleagues who acted as students in micro-teaching class. Therefore, it mademe confused how to deal with them in my teaching practicum. (Soraya's Reflective joumal).

The written narrative shows that in spite of the chance she obtained to improve communication skills during the micro-teaching, her skill seemed not to work well during the teaching internship, since real students at schools were noisier than those involved in the micro-teaching course. This suggests that while student-teachers improved pedagogical competent in the micro-teaching, the skills were not necessarily applicable in real classrooms.

\section{Improving student-teachers' chalkboard skill}

Chalkboard skill is very important in the teaching and learning process. By using the chalkboard effectively, the teachers could make learning in the classroom more meaningful and appealing to students. Some participants mentioned that they gained benefits in terms of chalkboard skills. The chalkboard skill that they learned in micro-teaching really helped them to their teaching internship. Soraya stated:
"In the micro-teaching class I got some ways how to write on board that was really useful when I did teaching practicum. Just like how to write on the board in a proper way, for example I had to practice writing on the whiteboard without blocking my students. So, at the same time, I could control the students when I write on the board".

The ability to use whiteboard is indeed important for teaching success, and fortunately these student-teachers suggested that the micro-teaching course allowed them to learn how to manage whiteboard effectively.
Similarly, Vetra also suggested that microteaching helped her to use whiteboard effectively. She stated:

"We could divide our board into three spaces. We could use the first space for the main content of the lesson, the middle space for the material we teach and the third space to write new vocabulary that students did not know the meaning. So we could explain it clearly. It also allowed the student to take note of new vocabulary to remember it".

Vetra's written narrative also shows that she could write interestingly and creatively to capture students' attention in learning activities by using colored ink. She wrote in her written narrative that the micro teaching has helped her learn how to write well on the white board. She wrote:

I used colored ink to highlight some important points related to the materials. Sometimes I underlined the words and sentences with different colors to give emphasis that I thought necessary to take a note in my teaching. Such as I used the blue color to underline any kind to be of the present tense (am, is, are) and the red color for past tense (was, were). (Vetra's Reflective Joumal).

In addition, Iqbal and Alex also perceived micro-teaching as helping them in managing the board when they took the teaching internship course. Iqbal stated

"We had to make sure that we did not write too much on the board because a cluttered chalkboard may confuse our students. Also, I had to make sure the size of my handwriting could be seen clearly by students. As we know that the students in the back rows may have trouble reading small words".

\begin{abstract}
Alex also mentioned
"Micro-teaching class also assisted me to allow having sufficient time to copy what I have written before I erased it. Also, the most important thing was the micro-teaching class taught me to erase all my words on the whiteboard after finishing my teaching".
\end{abstract}

Alex also noted in his written narrative:

When I made some points, I did not talk to the chalkboards. I had to stop writing and giving students a chance to think and discuss it. After that, I summarized and wrote it without losing their attention. Also, I provided the opportunity for students to wnite it on the board. If only I explained and wrote it, it made my students be bored and sleepy on the back. It was a good thing that assisted my teaching at school. (Alexs's Reflective Joumal).

This was evident from the following excerpt taken from Alex's reflection. Writing on the board efficiently was an important skill in teaching. It also became one of the teaching aids to transfer knowledge for students by writing some points on the board. Also, it allowed students to give ideas and made them engage in the classroom. This skill is indeed useful during teaching internship.

The data suggested that micro-teaching has allowed students to use whiteboard accordingly. They find it very useful to have learned how to manage writing on the board during their micro- 
teaching class, which then allow them to have used whiteboard accordingly during teaching internship.

\section{Increasing student-teachers' questioning skill}

The other important finding suggests that studentteachers learnt to improve their questioning skills in the micro-teaching course, which was very useful for teaching internship. Nelly, for example said that "I have learnt how to ask question in my microteaching, which help me use the skill during my teaching internship". This notion was also voiced by Zulfi.

She wrote in her narrative:

In my class, there were students who did not give a response to anything that we discussed. In order to get the silent students to be active in the class, I asked them some questions to arouse interest in leaming. (Zulfi's Reflective Joumal).

Zulfi wrote that she indeed learn how to ask question during teaching practices. This skill helped her in teaching internship.

\section{Developing student-teachers' reinforcement skill}

The other important perceived benefit of the microteaching was the fact that students learn to improve their reinforcement skills. The skill is very useful in teaching profession, since through which teachers praise and give reward to their students. It was very fortunate that student-teachers have the chance to learn the skill during the micro-teaching course. Mawar, for example mentioned:

"Micro-teaching helped me to know how to use praise words in the classroom. We could use words such as "good", "excellent", "smart", "nice answer "and "genius" for the student who answered the questions from the teacher. It also made them be confident and brave. I should smile to students so that students did not feel the burden during the learning activities"

Zulfi also stated that the micro-teaching helped her to gain knowledge on how to give reward for students' success. She stated that:

"It helped me to get some ideas to give rewards for the student who could answer my questions and finish their tasks quickly. I gave a reward like pens, candies, books. So, in teaching practicum, my students were more enthusiasts during the learning process"

The data suggests that the micro-teaching has contributed significantly to student-teachers' readiness in the teaching internship.

Apart from the perceived benefit of microteaching, the research also reveals data on teaching aspect left uncovered during the course.

\section{Teaching skills left uncovered}

Three important aspects were perceived as insufficiently covered during the micro-teaching course.

\section{Classroom management skill}

The majority of student-teachers argued that the micro-teaching did not give adequate preparation for them in terms of classroom management skills. Zulfi stated that "the micro teaching course did not give her sufficient time to improve her classroom management skills". For that reason, she found it difficult to do classroom management during the teaching internship, she stated that:

"I had problems in classroom management because I have forty students with different personalities and knowledge. It's hard when I taught them the materials. The overload student, it made the classroom was noisy. When I asked them to be quiet sometimes it was only just for five minutes maybe they were silent and then going on again"

In addition, Iqbal mentioned that it was difficult for him to handle various students' characters in the classroom during teaching internship, and this was so because he did not receive sufficient exposure on classroom management during the micro-teaching course.

In similar way, Tansa mentioned that the microteaching did give her sufficient exposure on classroom management, and thus it contributed to her lack of ability in managing her class during teaching internship.

\section{Lesson plan skill}

The other teaching aspect left uncovered was the exposure to design lesson plans. Some of them stated that they did not have enough preparation on how to design lesson plans properly. They needed more training in designing good lesson plans based on the rules of the government. This insufficient exposure led to their lack of ability to design lesson plan during teaching internship. Nelly stated that:

"In micro-teaching I learned how to teach by using curriculum 13, but in teaching internship, I must teach by using KTSP. It was difficult for me to implement KTSP to students because I didn't get enough knowledge on how to create the content of KTSP. In micro-teaching, we just focused on how to design curriculum 13".

In addition, Soraya stated that it was difficult for her to choose teaching materials that fit students' competences. She felt that micro-teaching did not provide her experience in adjusting the appropriate activities for certain levels of students. As she mentioned:

"The curriculum 13 that I have designed was not suitable to the level of the students because the school that I did teaching internship was located in the rural area, which has not implemented the K13 yet".

The data showed that the student-teachers found it difficult to design and implement the lesson plan during teaching internship. This was because of lack of exposure to design lesson plan during the microteaching course. 


\section{Time management skill}

The majority of participants assumed that microteaching did not help them in managing time during their teaching internship. Tansa, for example stated:

"In the time management was the difficult one during my teaching internship. The students were always coming late even though they lived in the hostel, so the time that I have set for the materials was not achieved. As a result, I didn't have enough time to teach all the materials".

In addition, some participants explained that time-management skill was not sufficiently received during the micro-teaching, which then led them to complexities in managing their teaching time during the internship.

Soraya wrote in the journals also indicated that she faced obstacles in managing time. She must repeat the explanation more until the students comprehend the lessons. This evident from the following excerpt taken from what she has written:

Sometimes I have set time for some activities but it did not work. Some theories were difficult for my students. They were confused and did not understand the lesson. It took more time to explain it clearly and made them understood. So, I could not continue to another topic just to make sure that they got it. (Soraya's Reflective joumal).

This narration shows that in the micro-teaching course, she found it difficult to manage time effectively, and this lack of skill was also felt during the teaching internship course.

The data suggests that these three issues; classroom management skill; time management skills, and skill to design lesson plan were not covered sufficiently during the micro-teaching course.

\section{DISCUSSION}

The purposes of this study are to find out studentteachers' perceptions on the benefits they obtained from micro-teaching class to their teaching internship and to identify the least aspects of teaching that have not been sufficiently covered in micro-teaching

This research shows the extent student-teachers develop their teaching competence. These students have experienced learning in the micro-teaching class, and thus these learning experiences have helped them gain insights on instructional process during the internship program (see Colliander, 2017; Nesje et al., 2017). Teachers' teaching competence is developed not in a vacuum; it is shaped through context sand experiences. These students have shown some shifts in their professional identity from being in the micro-teaching course to the teaching internship settings.

The data suggests that participants perceived micro-teaching to have given sufficient preparation for their teaching internship. Six benefits were identified from the research. The micro-teaching course has helped them boost their confidence; improve teaching strategies; enhance communication skill; improve chalkboard skills; increase questioning skill; and developing student-teachers' reinforcement skill. Some of these benefits were also found in previous studies on similar issues. For example, studies by Kabilan (2013); Pence and Macgillivray (2008); and Rodriguez (2011) found that micro teaching helps student-teachers improve their confidence. Findings of Barkhuizen and Feryok's (2006); Ward and Ward's (2003); and Willard-Holt's (2001) research showed that micro teaching helped student-teachers gain their pedagogical content knowledge, and thus lets them improve their teaching competent.

The micro-teaching allows students to boost their confidence through the fact that they are required to teach at least twice or thrice during the micro-teaching course. The teaching practices enable student-teachers to engage in transformational learning (Spear \& da Costa, 2017). The studentteachers can boost their confidence through repetition of teaching practices.

The micro-teaching course also enabled students to improve teaching awareness and strategies due to the fact that they got constant feedback from peers and mentors. According to Chaudary et al. (2015) micro-teaching gives chances for student-teachers to be aware of their teaching strategies through peers' and mentors' feedbacks. Skovholt (2017) stated that feedback is indeed a central part in any professional development activities. He argued that in fact through feedback, professional competence will be developed. This was evident from the data that through peers' and mentors' feedback did student-teachers shape their professional competence.

In addition, the communication skill of studentteachers was also improved during the microteaching, which benefitted them during their teaching internship. Student-teachers' involvement in teaching practices in the micro-teaching class allowed them to build communication skill. Students practiced how to communicate well as they got feedback from their peers and mentors. In addition, the repetition of teaching practices also allowed student-teachers to learn how to use whiteboard efficiently and effectively. This was because of the extensive feedback given by their peers and teachers. As the micro-teaching course allowed studentteachers to interact with their peers, their questioning skill were also developed, which was then useful for them in teaching internship.

In addition, mentors' explanation on good ways of communicating has helped student-teachers to develop reinforcement skills, such as the ability to praise students' work during the internship program. Reinforcement skills are indeed important in instructional process. Moore (2000) suggests that taking care of affective domain of the students were the concerned educational practitioners of all time. Skinner's theory, for example suggests that watching 
students' well-being should be the concern of all teachers (Moore, 2000). The theory suggests that giving a high level of reinforcement for students enhance the possibilities of learning success.

It is very fortunate to understand that studentteachers at our university taking the micro-teaching class received certain level of reinforcement skills, which then shaped their professional competence upon taking teaching internship at real schools.

In spite of benefit gained from micro-teaching class, the data also reveals that some aspects were left uncovered by mentors during the micro-teaching course. Time constraints were the main contributor that inhibits mentors to cover classroom management; time management issues; and also designing lesson plans.

\section{CONCLUSIONS}

Micro-teaching class has been found to be beneficial for student-teachers that help them during teaching internship. These participants have suggested at least six benefits they received from the micro-teaching program that enabled them to be better teacher candidates during the teaching internship. These student-teachers argued that teaching practices they experienced during the course was significant in boosting their confidence; allowing them to be aware of their teaching strategies; helping them improve communication; questioning skills; chalkboard and reinforcement skills. However, they also argued that they were not exposed very much to design the lesson plan, classroom and time management skills during the micro-teaching course. This research suggests that the combination of the two courses: the microteaching class and the internship program are necessary in the attempt to produce highly qualified teacher candidates.

\section{REFERENCES}

Alibakhshi, G., \& Dehvari, N. (2015). EFL teachers' perceptions of continuing professional development: A case of Iranian high school teachers. Profile, 17(2), 29-42. http://doi.org/10.15446/profile.v17n2.44374

Babbie, E. (2016). The basic of social research (7th ed.). Cengage Learning.

Barkhuizen, G., \& Feryok, A. (2006). Pre-service teachers' perceptions of a short-term international experience programme. Asiapacific Journal of Teacher Education, 34(1), 115-134. https://doi.org/10.1080/13598660500479904

Bulut, M. (2016). Effect of microteaching applications practiced by the pre-service teachers in the scope of first Turkish reading and writing lesson on their verbal communication skills. Universal Journal of
Educational Research, 4(12), 2863-2874. https://doi.org/10.13189/ujer.2016.041221

Chaudhary, N., Mahato, S. K., Chaudhary, S., \& Bhatia, B. D. (2015). Micro teaching skill for health professionals. Journal of Universal College of Medical Sciences, 3(1), 60-64. https://doi.org/10.3126/jucms.v3i1.13264

Colliander, H. (2018). The experienced newcomer The (trans)forming of professional teacher identity in a new landscape of practices. Teaching and Teacher Education, 69, 168-176. https://doi.org/10.1016/j.tate.2017.10.012

Creswell, J. W. (2014). Research design: Qualitative, quantitative, and mixed methods approaches. Sage Publication

Ekşi, G. Y., \& Yakışık, B. Y. (2016). To be anxious or not: student teachers in the practicum. Universal Journal of Educational Research, 4(6), 1332-1339. https://doi.org/10.13189/ujer.2016.040610

Glesne, C. (2015). Becoming qualitative researchers (5th ed.). Pearson.

Gibb, G. R. (2018). Analysing qualitative data (2nd ed.). Sage Publication.

Hastings, W., \& Squires, D. (2002). Restructuring and reculturing: Practicum supervision as professional development for teachers. AsiaPacific Journal of Teacher Education, 30(1), 79-91. https://doi.org/10.1080/13598660120114995

Kabilan, M. K. (2013). A phenomenological study of an international teaching practicum: Preservice teachers' experiences of professional development. Teaching and Teacher Education, 36, 198-209. http://dx.doi.org/10.1016/j.tate.2013.07.013

Kılıç, A. (2010). Learner-centered microteaching in teacher education. International Journal of Instruction, 3(1). 77-100. https://eric.ed.gov/?id=ED522934

Mohajan, H. K. (2018). Qualitative research methodology in social sciences and related subjects. Journal of Economic Development, Environment and people, 7(01), 23-48. https://mpra.ub.uni-muenchen.de/85654/

Moore, A. (2000). Teaching and learning: Pedagogy, curriculum, and culture. Routledge.

Nesje, K., Canrinus, E. T., \& Strype, J. (2018). "Trying on teaching for fit" Development of professional identity among professionals with multiple career opportunities. Teaching and Teacher Education, 69, 131-141. https://doi.org/10.1016/j.tate.2017.10.011

Özbal, A. F. (2019). Implementation of microteaching in special teaching methods $i$ and ii courses: an action research. International Education Studies, 12(10), 89-95. https://doi.org/10.5539/ies.v12n10p89

Pence, H., \& Macgillivray, I. (2008). The impact of an international field experience on preservice 
teachers. Teaching and Teacher Education, 24(1), 14-25.

https://doi.org/10.1016/j.tate.2007.01.003

Rahayuningsih, D. (2016). Student teachers' challenges in developing teaching materials during teaching practicum in vocational school. Journal of English and Education, 4(2), 24-34.

https://ejournal.upi.edu/index.php/L-

E/article/view/4629

Remesh, A. (2013). Microteaching, an efficient technique for learning effective teaching. Journal of Research in Medical Sciences, 18(2), 158-163.

https://www.ncbi.nlm.nih.gov/pmc/articles/PM C3724377/

Rodriguez, E. (2011). Reflections from an international immersion trip: new possibilities to institutionalize curriculum. Teacher Education Quarterly, 28(1), 147-160. https://eric.ed.gov/?id=EJ914928

Saban, A., \& Çoklar A. N. (2013). Pre-service teachers' opinions about the micro teaching method in teaching practice classes. The Turkish Online Journal of Educational Technology, 12(2), 234-235. http://www.tojet.net/articles/v12i2/12221.pdf

Şen, A. İ. (2009). A Study of effectiveness of peer microteaching in a teacher education program. Ĕgitim veBilim-Education and Science, 34(151), 165-174.

http://egitimvebilim.ted.org.tr/index.php/EB/ar ticle/view/616

Şen, A. İ. (2010). Effect of peer teaching and microteaching on teaching skills of pre-service physics teachers. Ĕ̈itim ve Bilim-Education and Science, 35(155), 78-88.

http://egitimvebilim.ted.org.tr/index.php/EB/ar ticle/view/562

Silverman, D. (2017). Doing qualitative research (5th ed.). Sage Publication.

Silverman, D. (2020). Interpreting qualitative data (6th ed.). Sage Publication

Skovholt, K. (2018). Anatomy of a teacher student feedback encounter. Teaching and Teacher Education, 69, 142-153. https://doi.org/10.1016/j.tate.2017.09.012
Spear, A. M., \& da Costa, R. B. (2018). Potential for transformation? Two teacher training programs examined through a critical pedagogy framework. Teaching and Teacher Education, 69, 202-209. https://doi.org/10.1016/j.tate.2017.10.013

Tuli, F., \& File, G. (2009). Practicum experience in teacher education. Ethiopian Journal of Education and Science, 5(1), 107-116. https://doi.org/10.4314/ejesc.v5i1.56316

Uzun, N. (2012). A sample of microteaching in environmental education and its effect on preservice teachers' presenting effective lessons. Asia-Pacific Forum on Science Learning and Teaching, 13(1). https://www.eduhk.hk/apfslt/v13_issue1/uzun/i ndex.htm

Ward, M. J., \& Ward, C. J. (2003). Promoting crosscultural competence in preservice teachers through second language use. Education, 123(3), 532-536. https://www.researchgate.net/publication/2927 37416_Promoting_Cross-

Cultural_Competence_in_Preservice_Teachers _through_Second_Language_Use

Willard-Holt, C. (2001). The impact of a short-term international experience for preservice teachers. Teaching and Teacher Education, 17, 505-517. https://doi.org/10.1016/S0742051X(01)00009-9

Yilmaz, C. (2018). Investigating pre-service EFL teachers' self-concepts within the framework of teaching practicum in Turkish context. English Language Teaching, 11(2), 156-163. https://doi.org/10.5539/elt.v11n2p156

Zeichner, K. (2010). Rethinking the connection between campus courses and field experiences in college- and university-based teacher education. Journal of Teacher Education, 1(2), 61-89.

https://doi.org/10.1177\%2F002248710934767 1

Zulfikar, T. (2009). The making of Indonesian Education, Journal of Indonesian Social Sciences and Humanities, 2, 13-39. https://doi.org/10.14203/jissh.v2i0.19 